\title{
Copyright, Open Access Policies and Publishing
}

\author{
Ionela Maria Bârsan \\ PhDc, Transilvania University of Brasov, Romania \\ E-mail o.barsan@yahoo.com
}

Open Access and Open Science are ways of sharing knowledge between research communities and networks. This article presents important projects, ROARMAP and Sherpa RoMEO, that aim to identify publishers that allow open access publishing. An analysis of the data provided by these projects shows the weak involvement of Romania.

Keywords: Open Access policies; publishing; editors; Romania

\section{Introduction}

According to Suber (2012), "open access literature is digital, online, free of charge, and free of most copyright and licensing restrictions". Nowadays, more and more universities, research institutes, publishers developed open access policies. Open access is making scientific research publications freely, immediately and permanently available online for everyone to read and download.

The Open Access movement was born in academic communities as a reaction to the high expenses universities have to cover in order to publish and access scientific information. The gold and green open access routes proposed by academic communities were not easily implemented. The huge barrier was the copyright issue. Regarding copyright issues, Open Access publishing lets the author keep the copyright to his own work and gives users permission to make available, copy, distribute, build upon, search in, or text mine from the full-text without compensation.

Because of this, many projects were developed to implement tools, platforms with new copyright rules for publishing in Open Access. Editors also had to develop policies and agreements with authors in order to publish in Open Access. This is an important step in the information society: having access to scientific information while respecting copyright rights.

\section{Researches about policies for Open Access publishing}

The Registry of Open Access Repository Mandates and Policies (ROARMAP) is "a searchable international registry charting the growth of open access mandates and policies adopted by universities, research institutions and research funders that require or request their researchers to provide open access to their peer-reviewed research article output by depositing it in an open access repository" (ROARMAP 2018b). Institutional policies are developed in accordance with the recommendation of Berlin Declaration.

According to ROARMAP data, 726 mandates were registered at October 11, 2018.

An overview of the situation in European countries is presented in Figure 2 and the only institution in Romania is the Institute of World Economy (ROARMAP 2018a). 


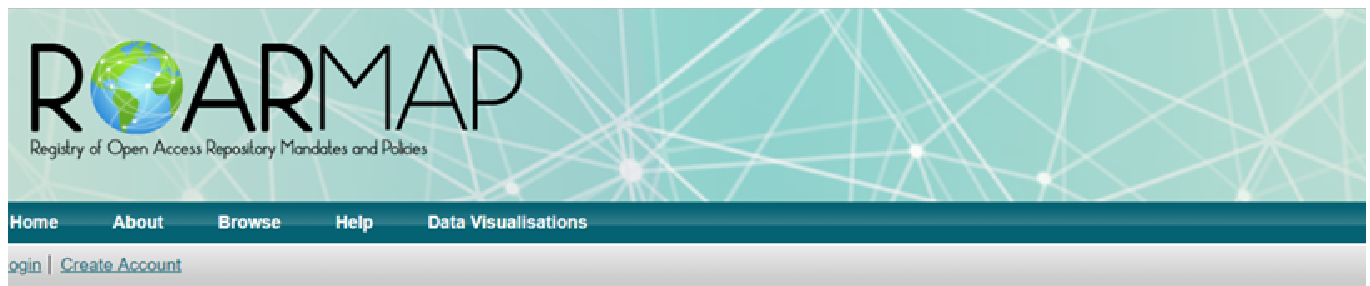

Welcome to ROARMAP

The Registry of Open Access Repository Mandates and Policies (ROARMAP) is a searchable international registry charting the growth of open accoss mandates and policies adopted by universities, research institution se depositing it in an open access repository

Register a New Policy

Create a new policy record.

Search the Database

Search the database using a full range of fields. Use the search field at the top of the page for a quick search

Total Mandates (by type)

Figure 1. Registry of Open Access Repository Mandate and Policies (ROARMAP)

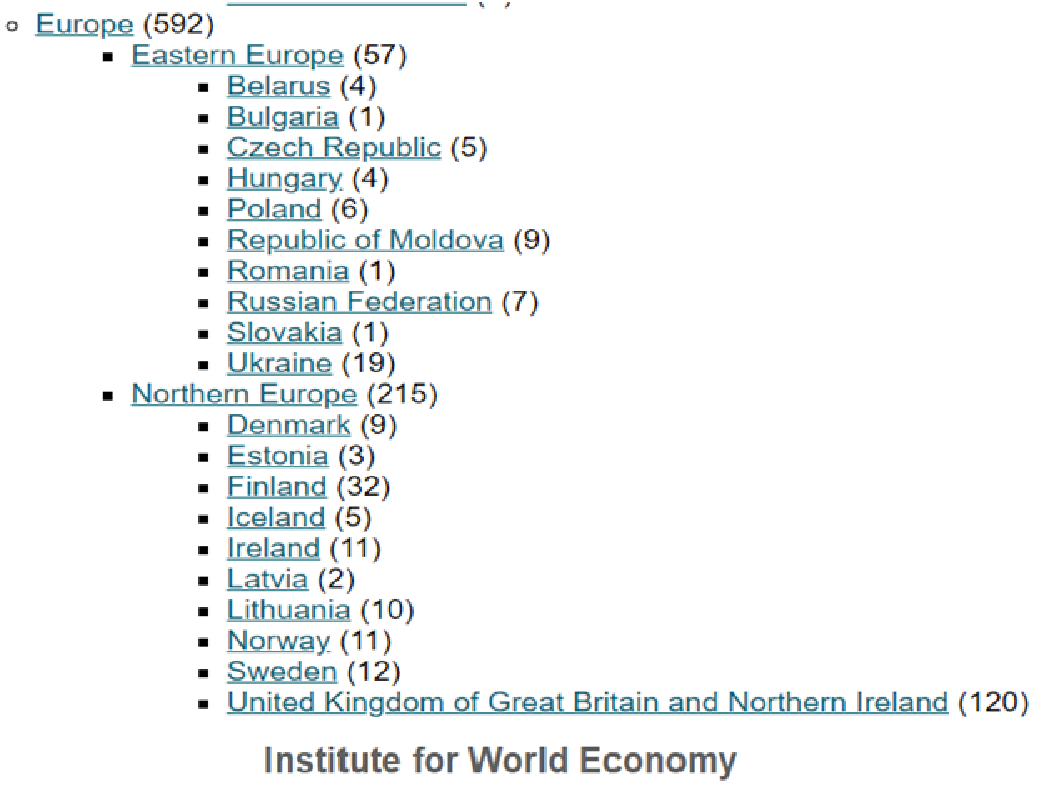

\section{General}

Country: Europe $>$ Eastern Europe $>$ Romania

Policymaker type: Research organisation (e.g. university or research institution)

Policymaker name: Institute for World Economy

Policymaker URL: http://www.iem.rol

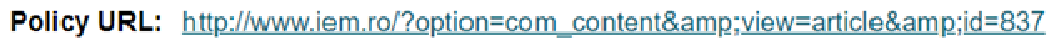

Repository URL: http://www.nos.iem.rol

Policy adoption date: 3 February 2015

Policy effective date: July 2015

Source of policy: Administrative/management decision

Figure 2. Countries' situation about registry of policies - situation in Romania 
The policies issued by different research institutions as part of the fund granting process are made available for reading by the specialized register maintained by the University of Nottingham in England - SHERPA JULIET (SHERPA Services 2018).

In 2018, 133 policies of the funding agencies from England (63), Canada (14), USA (16), Denmark (3), Ireland (6), Sweden (5) were registered in SHERPA JULIET (SHERPA Services 2018).

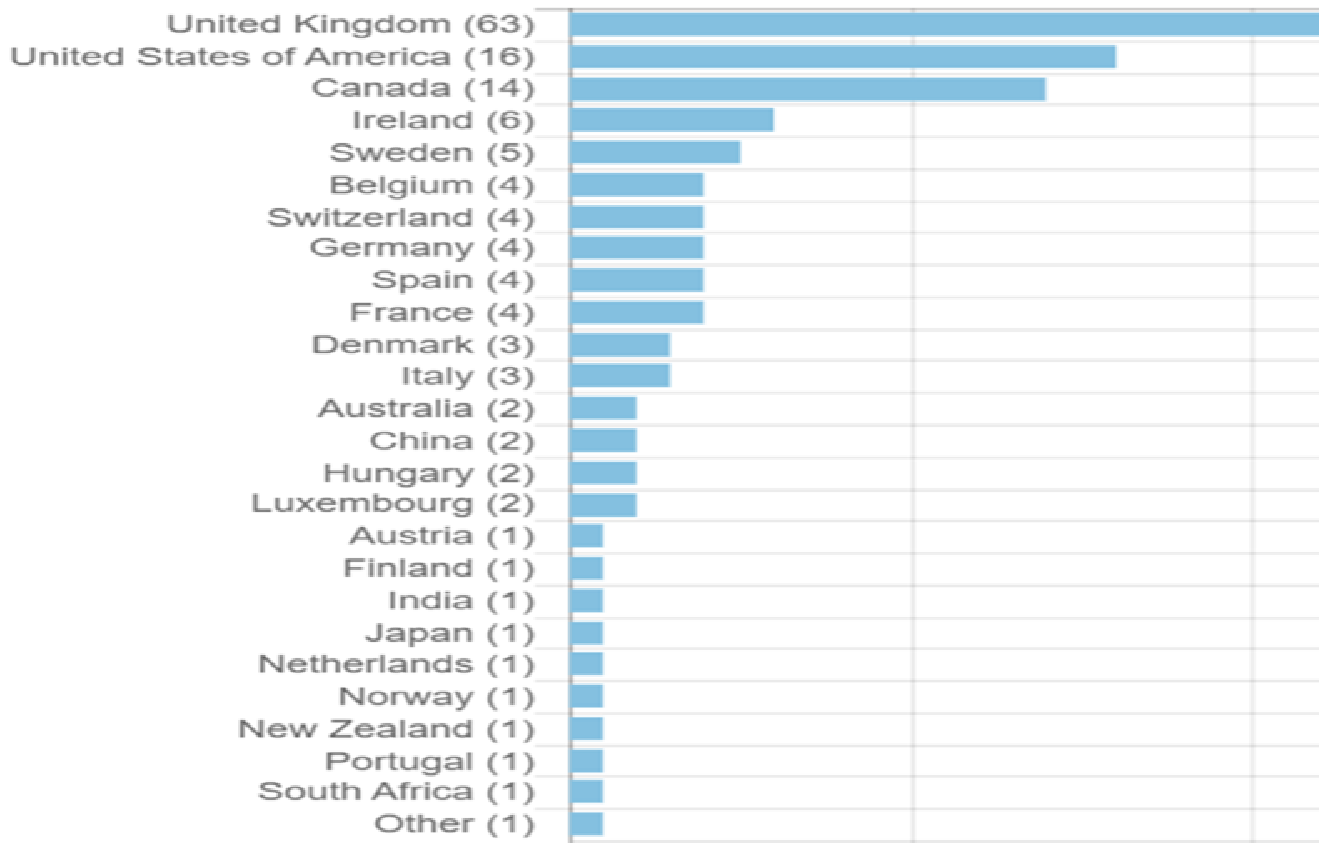

Figure 3. Countries' situation in Sherpa JULIET

The ROMEO (Rights MEtadata for Open Archiving) project, whose maintenance is carried out by SHERPA at the University of Nottingham, proposes three policies (each of which is color-coded) concerning the self-archiving of articles in the repositories.

There are 2566 publishers in the ROMEO list (SHERPA 2018), of which 81\% formally accepts certain forms of self-archiving.

\begin{tabular}{|c|l|c|c|}
\hline RoMEO colour & \multicolumn{1}{c}{ Archiving policy } & Publishers & $\%$ \\
\cline { 2 - 3 } green & Can archive pre-print and post-print & 1055 & 41 \\
\hline blue & Can archive post-print (ie final draft post-refereeing) & 848 & 33 \\
\hline yellow & Can archive pre-print (ie pre-refereeing) & 175 & 7 \\
\hline white & Archiving not formally supported & 488 & 19
\end{tabular}

Figure 4a. Self-archiving policy within the SHERPA ROMEO project

Specifying editorial policies on copyright issues has contributed to changing colours to designate these policies. Thus, instead of three, four colours were introduced (Jenkins et al. 2007):

- green policy - allows achieving of pre-prints and post-prints; also, there are no chronological limits (embargo) and there are certain copyright conditions;

- blue policy - allows the author to self-archive only post-prints (the self-archiving of the preprints is not supported); 
- yellow policy - allows the author to self-archive pre-prints, self-archiving of post-prints is not supported or can be done with chronological limitations (embargo) and copyright conditions;

- white policy - self-archiving is not formally supported, it is necessary to obtain permission from the publisher (Figure 4a, 4b).

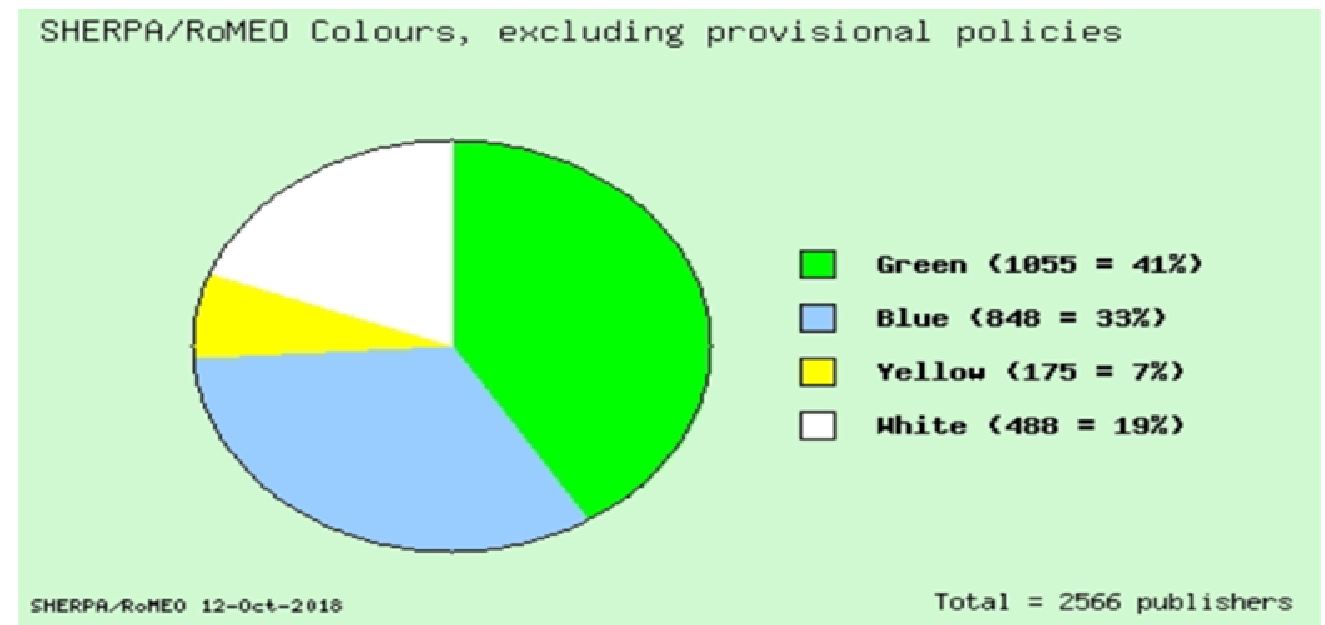

Figure 4b. Self-archiving policy within the SHERPA ROMEO project

The RoMEO Journals database is supplemented with information provided by:

- Zetoc service, funded by Jisc with data provided by the British Library (Zetoc 2018).

- Directory of Open Access Journal (DOAJ) managed by Infrastructure Services for Open Access (DOAJ 2018).

We can search the database for journal title, ISSN, publisher name, RoMEOcolour (see Figure 5).

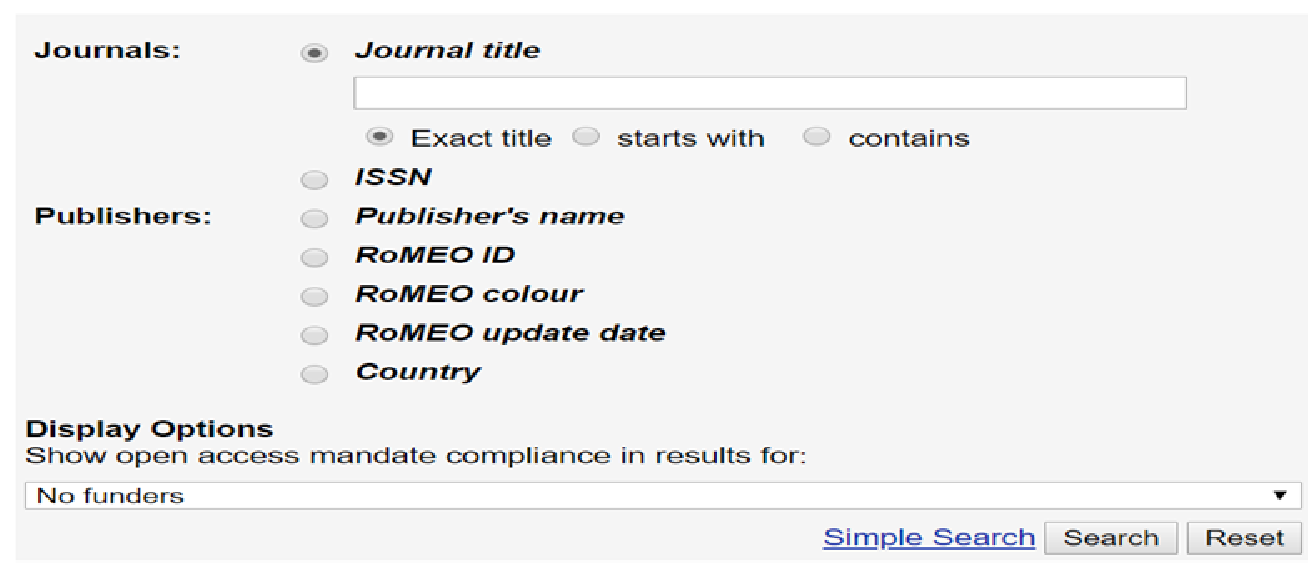

Figure 5. Searching RoMEO database

There are 27 publishers registered on this platform in Romania (see Figure 6). 
27 publishers found when searched for: Country: Romania

Important: Although publishers have default policies, individual journals may have special permissions, especially if they $i$ options. Always run a journal title or ISSN search to check.

Publisher (linked to the full RoMEO details)

Stefan cel Mare University of Suceava

Asociatia de Cooperare Cultural-Educationala Suceava

Digital ProScholar Media

Editura Economică

Editura Universitătii de Nord Baia Mare

Edusoft

Expert Journals

Free Mind Publishing

Institutul Naţional de Cercetare-Dezvoltare in Construcții, Urbanism și Dezvoltare Teritorială Durabilă (URBAN-INCERC)

Media Systems Communications

- Creative Commons Attribution Share Alike

National Agricultural Research and Development Institute (NARDI)
ROMEO Colour

White

Yellow

White

Blue

Yellow

Green

Blue

Green

White

Green

Green

Blue

Figure 6. Romanian publishers registered at RoMEO database

The growth of SHERPA/RoMEO database including provisional policies is shown in Figure 7.

In period 2004-2018, 2566 publishers recorded their policies of copyright in database. In 2008, these policies have been expanded by incorporating copyright-based publishing policies. Thus, a publishers' classification was made, considering their self-archiving conditions (Țurcan 2009).

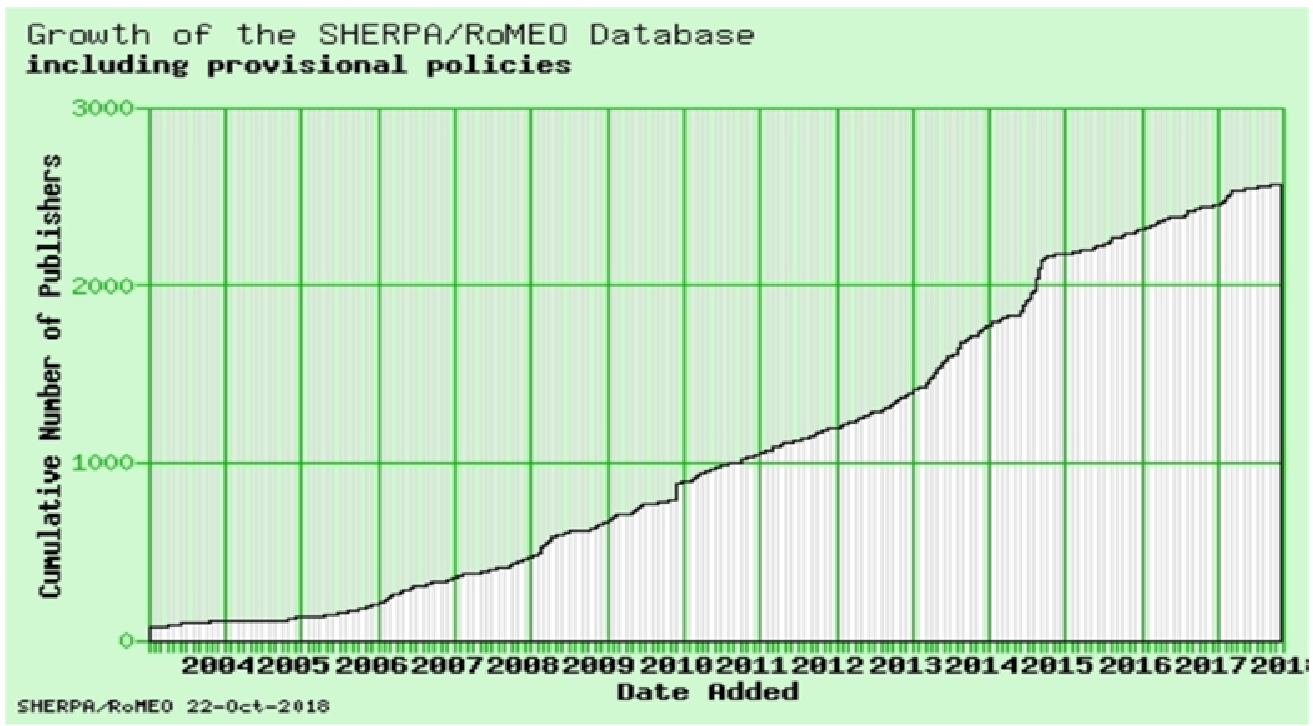

Figure 7. Growth of RoMEO database, 2004-2018

\section{Conclusions}

Policies on open access to scientific information can be implemented only on the basis of the highest (international and interstate) approval of initiatives and declarations regarding the open access to knowledge. Also, at national and institutional level, policies on non-discriminatory, democratic and free access to scientific information must be implemented. Scientific communication can be achieved only by approving new models that remove barriers to access to information (financial, legal and technical) as well as barriers to information sharing. The study of 
the two platforms demonstrates the rather weak involvement of Romanian higher education institutions in policy making and involvement in Open Access publishing. It is the recommendation of this article that Open Access must be promoted in a more efficient way to the members of the academic community.

\section{References}

DOAJ (Directory of Open Access Journals) (2018) [online], available: https://doaj.org [accessed 22 October 2018].

Jenkins, C., Probets, S., Oppenheim, C. and Hubbard, B. (2007) RoMEO Studies 8: self-archiving: The logic behind the colour-coding used in the Copyright Knowledge Bank, in Program, 41(2), pp. 124-133, available: https://doi.org/10.1108/00330330710742908.

Repanovici, Angela (2010) Promovarea producției ştiinţifice prin depozite digitale [Promoting scientific production through digital repositories], Bucureşti: Editura Academiei Române.

ROARMAP (Registry of Open Access Repository Mandates and Policies) (2018a) Institute for World Economy [online], available: http://roarmap.eprints.org/854 [accessed 12 October 2018].

ROARMAP (Registry of Open Access Repository Mandates and Policies) (2018b) Welcome to ROARMAP [online], available: http://roarmap.eprints.org [accessed 12 October 2018].

SHERPA (2018) SHERPA/RoMEO - Publisher copyright policies \& self-archiving [online], available: http://www.sherpa.ac.uk/romeo/index.php [accessed 12 October 2018].

SHERPA Services (2018) About Sherpa Juliet [online], available: http://v2.sherpa.ac.uk/juliet/ information.html [accessed 12 October 2018].

Suber, P. (2012) Open access [online], Cambridge, Mass.: MIT Press, available: http://bit.ly/ rrbsi32018g [accessed 12 October 2018].

Țurcan, N. (2009) Politicile accesului deschis în ţările în tranziţie [Open access policies in transition countries], in Biblio Scientia, 1-2 pp. 31-44.

Zetoc (2018). Zetoc: The monitoring and search service for global research publications [online], available: http://zetoc.jisc.ac.uk [accessed 22 October 2018]. 